\title{
Spatio-temporal occurrence of infections by the microsporidium Liebermannia dichroplusae
}

\author{
Carlos E. Lange ${ }^{1,2}$, Yanina Mariottini ${ }^{3}$, María Laura de Wysiecki ${ }^{1}$ \\ and María Marta Cigliano ${ }^{1,4}$
}

\author{
${ }^{1}$ Centro de Estudios Parasitológicos y de Vectores (CEPAVE), CCT La Plata \\ CONICET - Universidad Nacional de La Plata (UNLP), Argentina \\ ${ }^{2}$ Comisión de Investigaciones Cientificas de la Provincia de Buenos Aires \\ (CICPBA), Argentina \\ ${ }^{3}$ Instituto Multidisciplinario sobre Ecosistemas y Desarrollo Sustentable (UNICEN- \\ CICPBA), Tandil, Argentina \\ ${ }^{3}$ Museo de La Plata, División Entomología, Facultad de Ciencias Naturales, \\ Universidad Nacional de La Plata (UNLP), Argentina
}

| Submitted September 8, 2020 | Accepted October 18, 2020 |

\begin{abstract}
Summary
Liebermannia dichroplusae is an intracellular parasite that develops in the epithelium cells of the Malpighian tubules of the univoltine melanopline Dichroplus elongatus, a common and widespread grasshopper in southern South America that readily becomes an agricultural pest when outbreaks occur. Heavy infections by $L$. dichroplusae cause conspicuous pathologies and are clearly deleterious to the host. Transovarial transmission is the main route of infection in L. dichroplusae while horizontal transmission appears to be rare. The examination of 243 samples containing a total of almost 17.000 nymphs and adults of $D$. elongatus collected at 88 localities in eight provinces of Argentina between 1984 and 2017 showed that $L$. dichroplusae appears to occur only in the central-eastern Pampas region (Buenos Aires province) while its host inhabits almost the whole country. It is hypothesized that the relatively localized occurrence of $L$. dichroplusae compared to the wide geographical range of its host, could be the result of the combination of the dominant mode of transmission of the pathogen the pathologies it causes, and the main type of dispersal of $D$. elongatus.
\end{abstract}

Key words: Dichroplus elongatus, grasshopper, Pampas region, prevalence, transmission

\section{Introduction}

Microsporidia, historically often considered as protists due to the eukaryotic and unicellular con- dition, are now regarded as a monophyletic group of microorganisms closely related to the Cryptomycota or Rozellomycota (Wadi and Reinke, 2020). They are sporogenic, obligate intracellular parasites

doi:10.21685/1680-0826-2020-14-3-6 
of other protists and animals, with almost half of the 200 described genera having insects as type hosts (Andreadis and Becnel, 2014). As with other symbionts, transmission is a key factor driving the occurrence, persistence, and spread of microsporidia in their hosts (Agnew et al., 2003; Ebert, 2013; Hoch and Solter, 2017). The microsporidian genus Liebermannia comprises species that parasitize epithelium cells of the alimentary tract and associated organs and glands of grasshoppers (Orthoptera: Acridoidea) (Sokolova et al., 2009). Species of Liebermannia were thought to be endemic to southern South America but recently a microsporidium was discovered in the grasshopper Chorthippus loratus in South-Western Russia and was assigned to the genus on molecular grounds as an undescribed species (Ignatieva et al., 2019). The type species of the genus, L. dichroplusae, was originally described as Perezia dichroplusae but later transfer to Liebermannia (Sokolova et al., 2007). It develops in the Malpighian tubules of Dichroplus elongatus, a univoltine melanopline (Acrididae: Melanoplinae; Bardi and Lange, 2011) that is one of the most common and widely distributed grasshoppers of southern South America that readily becomes an agricultural pest when outbreaks occur (Lange and Cigliano, 2019a). In advanced or heavy infections, typically seen in older stages of the host (implying some host-pathogen synchronism in development), the Malpighian tubules are seriously disrupted in morphology and function. The tubules exhibit distinct pathologies from hypertrophy and cytoplasmic vacuolization of cells to blocking peristaltic and contortion movements of tubules thus impending the secretory process (Lange, 1987). As expected from a microsporidium of the alimentary canal (Solter et al., 2012), egress of spores with feces of the host occurs in L. dichroplusae but horizontal transmission has not been achieved despite multiple efforts (Lange and Cigliano, 2019b) while transovarial transmission was evidenced through experimental work (Lange, 1997). In the field $L$. dichroplusae occurs in the enzootic state (Lange, 1989, 2003) which means low prevalence and constant presence in a host population, as defined by Onstad et al. (2006). After decades of surveying grasshopper populations in Argentina for microsporidia with possible biocontrol potential we now have a reasonably good picture of the distribution of $L$. dichroplusae in its natural host. This communication reports on the occurrence of the species and its possible causes.

\section{Material and methods}

Adults and nymphs of D. elongatus were collected with entomological nets in rangeland, natural and disrupted grasslands, and crops in the vicinity of 88 localities from eight provinces in Argentina (Fig. 1). Most localities were in four provinces, Buenos Aires and La Pampa in the Pampas region, and Neuquén and Chubut in north-western Patagonia but some were in other four provinces in the North of the country (Jujuy, Entre Ríos, Córdoba, San Luis). Samples included in this study, consisted of all $D$. elongatus captured alive with 200-300 sweeps along transects in each collecting locality. Each sample contained at least 11 individuals (the lowest sample size at which $L$. dichroplusae was ever detected; Lange, 1989). Although a few localities in Buenos Aires and La Pampa were sampled only once, the vast majority were sampled on multiple seasons (up to eleven) while localities in Chubut (except Facundo, sampled once) and Neuquén were visited three and four to five times, respectively. Localities in Northern provinces were sampled once each (Jujuy and Entre Ríos) or twice (Córdoba and San Luis). Samples included spanned from 1984 to 2017, were collected typically from early January to early March when populations of $D$. elongatus are at their peak and represented mostly by adults and older nymphs (instars IV-V) (Mariottini et al. 2011). A total of 16741 D. elongatus grasshoppers originated from 243 samples were examined. Number of individuals in each sample ranged from eleven to 635 and averaged $70 \pm 6.7$ (SE). After collection, samples were frozen $\left(-32^{\circ} \mathrm{C}\right)$ for later processing. When deemed necessary identification as D. elongatus was corroborated by examination of characters of the male genitalia which are diagnostic for species delimitation within the D. elongatus species group (Ronderos et al., 1968; Cigliano and Lange, 2014; Castillo et al., 2017). For detection of L. dichroplusae, grasshoppers were thawed and examined microscopically either by homogenization or dissection methods as previously described (Lange, 2003). Organ tropism, gross pathological changes in the Malpighian tubules (Fig. 2), and morphology, size, and development of L. dichroplusae were identified as diagnostic features (Lange, 1987; 2003; Lange and Cigliano, 2019b). Although microscopic screening may underestimate real prevalence by not detecting early infections, such possibility may be somewhat counterbalanced by the overestimation caused occasionally by molecular 


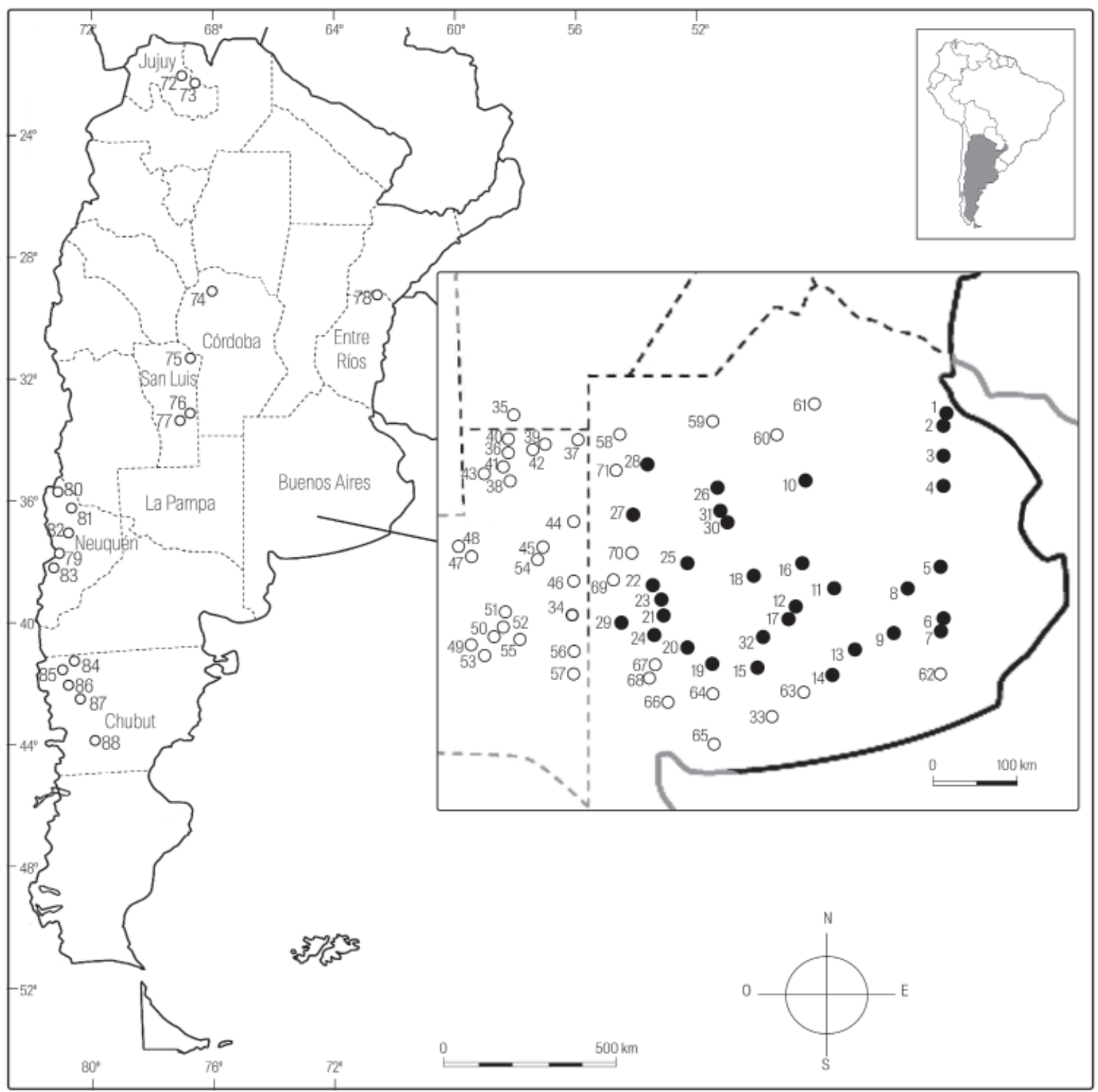

Fig. 1. Localities with detection (Black dots) and without detection (Empty dots) of Libermannia dichroplusae in Argentina and the Pampas region (Large inlet). 1, Quilmes. 2, Berazategui. 3, Brandsen. 4, Ranchos. 5 , Udaquiola. 6, Ayacucho. 7, Paraje San Alberto. 8, Rauch. 9, Tandil. 10, Saladillo. 11, Azul. 12, Olavarría. 13, María Ignacia. 14, Benito Juárez. 15, Laprida. 16, Tapalqué. 17, Empalme Querandíes. 18, Blancagrande. 19, Paraje San Eloy. 20, Coronel Suárez. 21, Guaminí. 22, Casbas. 23, Alamos. 24, Espartillar. 25, Daireaux. 26, Carlos Casares. 27, Trenque Lauquen. 28, Carlos Tejedor. 29, Carhué. 30, Bolívar. 31, Girondo. 32, General Lamadrid. 33, Tres Arroyos. 34, Macachín. 35, Huinca Renancó. 36, Ingeniero Luiggi. 37, Larroude. 38, Eduardo Castex. 39, Ojeda. 40, Quetrequén. 41, Caleufú. 42, Alta Italia. 43, La Maruja. 44, Lonquimay. 45, Anguil. 46, Riglos. 47, El Tropezón. 48, E1 Durazno. 49, El Carancho. 50, General Acha. 51, Utracán. 52, Quehué. 53, La Lonja. 54, Santa Rosa. 55, Resguardo Padre Buodo. 56, Guatraché. 57, Bernasconi. 58, General Villegas. 59, Lincoln. 60, Bragado. 61, Huergo. 62, Balcarce. 63, González Chávez. 64, Coronel Pringles. 65, Coronel Dorrego. 66, Tornquist. 67, Azopardo. 68, Bordenave. 69, Salliqueló. 70, Tres lomas. 71, Rivadavia. 72, Maimará. 73. Calilegua. 74, La Cumbre. 75, Cortaderas. 76, Buena Esperanza. 77, Bagual. 78, Chajarí. 79, Aluminé. 80, Andacollo. 81, El Huecú. 82, Loncopué. 83, Junín de Los Andes. 84, Gualjaina. 85, Esquel. 86, Tecka. 87, Gobernador Costa. 88, Facundo. 


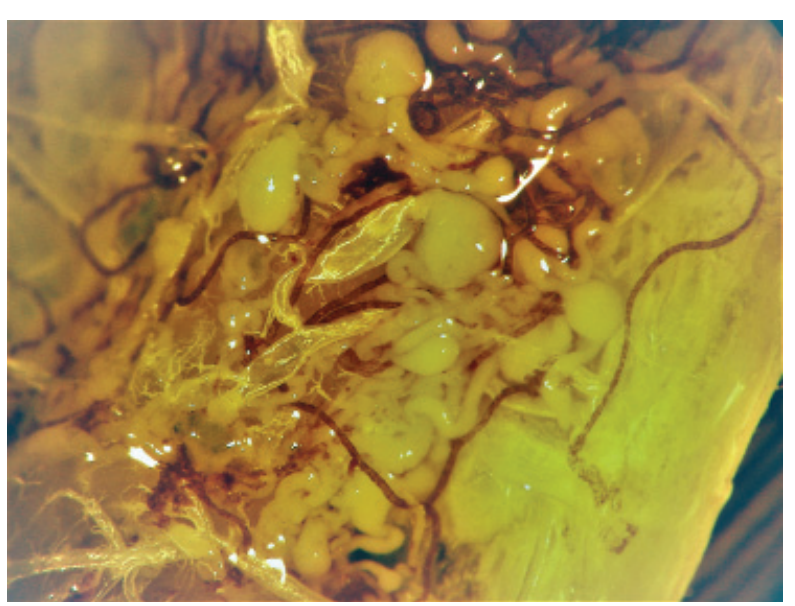

Fig. 2. Gross pathology caused by the microsporidium Liebermannia dichroplusae in the Malpighian tubules of the grasshopper Dichroplus elongatus. Uninfected or lightly-infected tubules seen as brownish, thin, thread-like structures while heavily-infected ones become hypertrophied, rounded, and whitish. Air sacs and trachea are seen as brightly transparent structures. Diameter of uninfected tubules is approximately $0.03 \mathrm{~mm}$.

methods, which due to their high sensitivity could detect transient (not infective) spores in the host gut (Hoch and Solter, 2017; Brown, 2017).

\section{Results}

Liebermannia dichroplusae was only detected in samples of the central-eastern Pampas region collected at 32 localities within Buenos Aires province (Fig. 1). Localities with presence were distributed in a relatively well-defined area spanning from approximately from $34^{\circ} 43^{\prime} \mathrm{S}$ to $37^{\circ} 40^{\prime} \mathrm{S}$ and from $58^{\circ} 16^{\prime} \mathrm{W}$ to $62^{\circ} 45^{\prime} \mathrm{W}$. Overall prevalence in the samples with detections was $6.3 \% \pm$ SE $0.3(n=$ 7416 specimens). When only large-size samples (i.e., 100 or more individuals of D. elongatus) were taken into account, the lowest recorded prevalence was 2.7 $\%(n=109)$ and the maximum one $22.3 \%(n=103)$. There was only other sample showing an unusually high prevalence of $19.8 \%(\mathrm{n}=101)$. Liebermannia dichroplusae was not detected in the remaining 56 samples $(n=9325)$ obtained from localities outside of Buenos Aires province and within the other seven provinces (Fig 1).

\section{Discussion}

Although the occurrence of a pathogen in host populations tends to be patchy and may vary greatly in space and time (Solter, 2014), our long-term survey for more than three decades resulted in a clear and stable pattern of $L$. dichroplusae distribution restricted to most of Pampas region except for its western area. Though evidencing the absence of the given pathogen in host populations may never be conclusively attained, our methodology and survey efforts were identical at areas with and without detections, which strongly suggested that the microsporidium was missing from host population of all examined areas except for Buenos Aires province. Within the area of occurrence, a relatively consistent collection of D. elongatus (around 100 individuals/sample) will likely reveal the presence of L. dichroplusae at the enzootic level with the mean prevalence of about $6.3 \%$. This is characteristic for the pathogens with the dominant transovarial and rare horizontal transmission routes (Fuxa and Tanada, 1987). Liberation of spores with feces and occasional detection of higher prevalence (up to $22.3 \%$ ) suggest that horizontal transmission occur but probably as a rare event under very especial conditions (Agnew et al., 2003). The observed geographical distribution of L. dichroplusae, limited to the central-eastern Pampas within Buenos Aires province (Fig. 1), is puzzling considering that D. elongatus is distributed all over Argentina but the island of Tierra del Fuego at the very South of the country (Lange and Cigliano, 2019a). We hypothesize that such phenomenon is connected with predominant vertical transmission route, with the pathologies the pathogen causes, coupled with certain behavioural characteristics of the host. $D$. elongatus is a sedentary grasshopper that does not normally perform swarm-like flights and remains in its immediate surroundings for most of the lifetime. Only late in the season some individuals fly away singly to disperse. Comprehensive studies on various aspects of different populations of $D$. elongatus in Argentina (Rosetti and Remis, 2012; Castillo et al., 2017) did not reveal the existence of cryptic unsusceptible species that would explain the absence of infections in some areas or populations. These studies revealed a previously unknown behaviour termed a 'male biased dispersal' when females remain much of the time at the relatively confined 
areas while males fly away. This feature coupled with predominant transovarial transmission, could explain the limited distribution of $L$. dichroplusae. Since venereal transmission from infected males to females is very rare in microsporidia and was not registered in L. dichroplusae (Becnel and Andreadis, 2014; Lange, 1997), it is likely that infections in males constitute a dead-end road. This would leave infected females in charge of dissemination of the pathogen. In addition, advanced or heavy infections are clearly deleterious (Fig. 2; Lange, 1987). They disrupt metabolism by blocking the excretion process which in turn may possibly reduce mobility and flight ability, as known for other entomopathogenic microsporidia (Hoch and Solter, 2017; Lange and Cigliano, 2005). Then dissemination of $L$. dichroplusae could rest on just lightly-infected adult females still able to fly, a small window of opportunity given that light infections occur mostly in non-flying nymphs.

Thus the obtained data allows us to speculate that the combination of the three factors (i) main or dominant type of transmission, (ii) pathologies involved, and (iii) aspects of the host behaviour, constrains geographical distribution of $L$. dichroplusae. As conceptualized by Ebert (2013), when dealing with persistence and dispersal of symbionts, combine traits of the involved parties can make a big difference for the functioning of the pathogen-host system.

\section{Acknowledgements}

To María Laura Morote for her excellent technical assistance.

\section{References}

Agnew P., Becnel J. J., Ebert D. and Michalakis Y. 2003. Symbiosis of microsporidia and insects. In: Insect Symbiosis (Ed. Kostas Bourtzis) CRS Press, Boca Raton, pp. 145-163.

Bardi C. and Lange C.E. 2011. Voltinism in the melanopline grasshopper Dichroplus elongatus Giglio-Tos (Orthoptera: Acrididae: Melanoplinae). Stud. Neotrop. Fauna Environ. 46, 143-145.

Becnel J.J. and Andreadis T.G. 2014. Microsporidia in insects. In: Microsporidia: Pathogens of opportunity (Eds. Weiss L.M. and Becnel J.J.) Wiley-Blackwell, Ames, Iowa, pp. 521-570.
Brown M.J.F. 2017. Microsporidia: An Emerging Threat to Bumblebees? Trends Parasitol. 33, 754-762.

Castillo E.R., Taffarel A., Maronna M.M., Cigliano M.M., Palacios O.M., Giménez D., Cab-ral Mello C. and Marti D.A. 2017. Phylogeny and chromosomal diversification in the Dichroplus elongatus species group (Orthoptera: Melanoplinae). PLOS one 12: https://doi.org/10.1371/journal. pone. 0172352 .

Cigliano M.M., Pocco M.E. and Lange C.E. 2014. Acridoideos (Orthoptera) de importancia agroeconómica en la República Argentina. In: Biodiversidad de Artrópodos Argentinos. Volumen 3 (Eds. Roig Junent S.A., Claps L.E. and Morrone J.J.), INSUE - Universidad Nacional de Tucumán, San Miguel de Tucumán, Argentina, pp. 1-36 (In Spanish).

Ebert D. 2013. The epidemiology and evolution of symbionts with mixed-mode transmission. Annu. Rev. Ecol. Evol. Syst. 44, 623-643.

Fuxa J.R. and Tanada Y. 1987. Epidemiological concepts applied to insect epizootiology. In: Epizootiology of insect diseases, (Eds. Fuxa J.R. and Tanada Y), John Wiley and Sons, NY, pp. 3-21.

Hoch G. and Solter L.F. 2017. Chapter 10: Microsporidia. In: Ecology of Invertebrate Disease (Eds. Hajek A. and Shapiro-Ilan D.), John Wiley and Sons, Hoboken, pp. 377-412.

Ignatieva A., Gerus A.V., Senderskiy I.V., Malysh S.M., Dolzhenko V.I. and Tokarev Y.S. 2019. Infection of Chorthippus loratus (Orthoptera: Acrididae) with Liebermannia sp. (Microsporidia) in South-Western Russia. J. Euk. Microbiol. 66, 680-683.

Lange C.E. 1987. Histopathology in the Malpighian Tubules of Dichroplus elongatus (Orthoptera: Acrididae) infected with Perezia dichroplusae (Microspora: Pereziidae). J. Invertebr. Pathol. 50, 146150.

Lange C.E. 1989. Prevalence of Perezia dichroplusae (Microspora: Pereziidae) in Argentine Grasshoppers (Orthoptera: Acrididae). J. Invertebr. Pathol. 54, 269-271.

Lange C.E. 1997. Vertical transmission of Perezia dichroplusae Lange (Protozoa: Microspora) in its natural host, Dichroplus elongatus Giglio-Tos (Orthoptera: Acrididae). Neotrópica 43, 39-42 (In Spanish with English summary).

Lange C.E. 2003. Long-term patterns of occurrence of Nosema locustae Canning and Perezia dichroplusae Lange (Microsporidia) in grasshoppers 
(Orthoptera: Acrididae) of the Pampas, Argentina. Acta Protozool. 42, 309-315.

Lange C.E. and Cigliano M. M. 2005. Overview and perspectives on the introduction and establishment of the grasshopper biocontrol agent Paranosema locustae (Canning) (Microsporidia) in the western Pampas of Argentina. Vedalia 12, 61-84.

Lange C.E. and Cigliano M. M. 2019a. Elongated grasshopper, Dichroplus elongatus Giglio-Tos, 1894 (Orthoptera: Acrididae). In: Encyclopedia of Pest Orthoptera of the World, (Eds. Lecoq M. and Zhang L.), China Agricultural University Publisher, Beijing, pp. 79-82.

Lange C.E. and Cigliano M.M. 2019b. Rare case of Microsporidia co-infection in the grasshopper Dichroplus elongatus (Orthoptera: Acrididae: Melanoplinae). Protistology 13, 14-18.

Mariottini Y., De Wysiecki M.L. and Lange C.E. 2011. Seasonal occurrence of life stages of grasshoppers (Orthoptera: Acridoidea) in the southern Pampas, Argentina. Zool. Stud. 50, 737-744.

Onstad D.W., Fuxa J.R., Humber R.A., Oestergaard J., Shapiro-Ilan D.I., Gouli V.V., Anderson R.S., Andreadis T.G. and Lacey L.A. 2006. An abridged glossary of terms used in invertebrate pathology, $3^{\text {rd }}$ edition. Society for Invertebrate Pathology, http://sipweb.org/glossary.

Ronderos R.A., Carbonell C.S. and Mesa A. 1968. Revision of genus Dichroplus Stal of the elongatus group (Orthoptera, Acrididae). Rev. Mus. La Plata. 10, 271-325 (In Spanish with English summary).

Rosetti N. and Remis I. 2012. Spatial genetic structure and mitochondrial DNA phylogeography of Argentinean populations of grasshoppers Dichroplus elongatus. PLOS one, 7: e40807.

Sokolova Y.Y., Lange C.E. and J.R. Fuxa. 2007. Establishment of Liebermannia dichroplusae n. comb. on the basis of molecular characterization of Perezia dichroplusae Lange, 1987 (Microsporidia). J. Euk. Microbiol. 54, 223-230.

Sokolova Y.Y., Lange C.E., Mariottini Y. and Fuxa J. 2009. Morphology and taxonomy of the microsporidium Liebermannia covasacrae from the grasshopper Covasacris pallidinota (Orthoptera: Acrididae). J. Invertebr. Pathol. 101, 34-42.

Solter L. 2014. Epizootiology of Microsporidiosis in Invertebrate hosts. In: Microsporidia: Pathogens of opportunity. (Eds. Weiss L.M. and Becnel J.J.). Wiley-Blackwell, Ames, Iowa, pp. 165-194

Solter L.F., Becnel J.J. and Oi D.H. 2012. Microsporidian entomopathogens. In: Insect Pathology, $2^{\text {nd }}$ edition. (Eds. Vega F.E. and Kaya H.K.).Elsevier, London, pp. 221-263.

Wadi L. and Reinke A.W. 2020. Evolution of microsporidia: An extremely successful group of eukaryotic intracellular parasites. PLOS Pathogens 16, e1008276.

Address for correspondence: Carlos E. Lange. CEPAVE, Boulevard 120 s/n entre Av. 60 y Calle 64, La Plata (1900), Argentina; e-mail: carlosl@cepave.edu.ar 